\title{
Allogeneic Transplantation in Chronic Myeloid Leukemia and the Effect of Tyrosine Kinase Inhibitors on Survival: A Quasi-Experimental Study
}

\author{
Kronik Myeloit Lösemide Allojenik Nakil ve Tirozin Kinaz Inhibitörlerinin Sağkalıma Etkisi Bir \\ Öncesi-Sonrası Çalışması
}

Mehmet Özen1, Celalettin Üstün2, Bengi Öztürk³, Pervin Topçuoğlu1, Mutlu Arat4, Mehmet Gündüz1, Erden Atilla1, Gülşen Bolat1, Önder Arslan1, Taner Demirer1, Hamdi Akan¹, Osman IIlhan11, Meral Beksaç¹, Günhan Gürman¹, Muhit Özcan1

\begin{abstract}
${ }^{1}$ Ankara University Faculty of Medicine, Department of Hematology and Bone Marrow Transplantation Unit, Ankara, Turkey
2 University of Minnesota, Department of Medicine, Division of Hematology-Oncology and Transplantation, Minneapolis, USA

${ }^{3}$ Ankara University Faculty of Medicine, Department of Internal Medicine, Ankara, Turkey

${ }^{4}$ Şişli Florence Nightingale Hospital, Clinic of Hematology, Istanbul, Turkey
\end{abstract}

\section{Abstract}

Objective: Tyrosine kinase inhibitors (TKIs) have changed the indications for allogeneic hematopoietic stem cell transplantation (allo-HSCT) in chronic myeloid leukemia (CML). Therefore, we aimed to evaluate the effect of TKIs on allo-HSCT in CML.

Materials and Methods: In this quasi-experimental study, we compared patient, disease, and transplantation characteristics as well as allo-HSCT outcomes between the pre-TKI era (before 2002) and the post-TKI era (2002 and later) in patients with CML. A total of 193 alloHSCTs were performed between 1989 and 2012.

Results: Patients in the post-TKI era had more advanced disease (>chronic phase 1) at the time of transplant and more frequently received reduced-intensity conditioning compared to patients in the pre-TKI era. Relapse/progression occurred more frequently in the year $\geq 2002$ group than in the year $<2002$ group (48\% vs. $32 \%$ at 5 years, $\mathrm{p}=0.01$ ); however, overall survival (OS) was similar in these two groups (5-year survival was $50.8 \%$ vs. $59.5 \%$, respectively; $p=0.3$ ). TKIs (with donor lymphocyte infusions or alone) for treatment of relapse after allo-HSCT were available in the post-TKI era and were associated with improved OS. While the rates of hematologic remission at 3 months after allo-HSCT were similar between TKI eras, patients having remission had better disease-free survival (DFS) [relative risk (RR): 0.15, confidence interval (Cl) 95\%: 0.09-0.24, $\mathrm{p}<0.001]$ and $0 \mathrm{~S}$ (RR: 0.14, Cl 95\%: 0.09-0.23, $\mathrm{p}<0.001$ ). Male allo-HSCT recipients had worse DFS (RR: 1.7, Cl 95\%: 1.2-2.5, p=0.007) and OS (RR: 1.7, Cl 95\%: $1.1-2.6, p=0.02)$ than females.

Conclusion: TKIs are an effective option for the treatment of relapse after allo-HSCT in CML. Hematologic remission after allo-HSCT is also an important factor for survival in CML patients.

Keywords: Chronic myeloid leukemia, Allogeneic transplantation, Tyrosine kinase inhibitors, Hematologic remission

\section{$\ddot{O z}$}

Amaç: Tirozin kinaz inhibitörleri (TKI) kronik myeloid lösemide (KML) allojenik hematopoetik kök hücre nakli (AHKHN) endikasyonlarını değiştirdi. Bu nedenle de biz KML'de TKI'nin AHKHN üzerine etkisini değerlendirmeyi amaçladık.

Gereç ve Yöntemler: Bu öncesi-sonrası çalışmasında KML'li hastalarda TKi öncesi dönem (yıl <2002) ve TKi sonrası dönem (yıl 22002) arasında hasta, hastalık ve nakil karakteristikleri ile AHKHN sonuçlarını kıyasladık. Toplamda 193 AHKHN, 1989 ve 2012 arasında yapıldı.

Bulgular: TKi sonrası dönemdeki hastalar, TKi öncesi döneme göre nakil sırasında daha ileri hastalığa (kronik faz 1'den ileri) sahipti ve daha sık azaltılmış yoğunluklu hazırlık rejimi aldı. Relaps/progresyon $\geq 2002$ grupta <2002 grubundan daha fazlaydı (5 yıllık \%32'ye karşın $\% 48 ; p=0,01)$; bununla birlikte toplam sağkalım (TS) bu iki grupta benzerdi (5-yıllık-sağkalım sırasıyla \%50,8'e karşın \%59,5; p=0,3). TKi tedavisi (verici lenfosit infüzyonu ile birlikte veya tek başına) AHKHN sonrası relaps tedavisinde TKI sonrası dönemde mevcuttu ve artmış TS ile ilişkiliydi. AHKHN sonrası 3. aydaki hematolojik remisyon oranları TKI dönemleri arasında benzer iken; remisyonda olan hastalar daha iyi hastalıksız sağkalıma (HsS) [Göreceli risk (GR): 0,15; \%95 güven aralığı (GA): 0,09-0,24; $p<0,001$ ] ve TS'ye sahipti (GR: 0,14; \%95 GA: 0,09$0,23 ; p<0,001)$. Erkek AHKHN alıcılarının HsS (GR: 1,7; \%95 GA: 1,2$2,5 ; p=0,007)$ ve TS'leri (GR: 1,7; \%95 GA: 1,1-2,6; $p=0,02$ ) kadınlardan daha kötüydü.

Sonuç: TKI, KML'de AHKHN sonrası relapsın tedavisinde etkin bir seçenektir. AHKHN sonrası hematolojik remisyon da KML hastalarında sağkalımda önemli bir faktördür.

Anahtar Sözcükler: Kronik miyeloid lösemi, Allojenik transplantasyon, Tirozin kinaz inhibitörleri, Hematolojik remisyon 


\section{Introduction}

Chronic myeloid leukemia (CML) is a clonal disease that originates from a translocation between chromosomes 9 and 22 (Philadelphia chromosome). This translocation fuses ABL1 at $9 q 34$ with BCR at 22q11.2, resulting in a chimeric gene that encodes an abnormal fusion protein. Before the discovery of tyrosine kinase inhibitors (TKIs), the median survival of CML patients in the blastic (BP), accelerated (AP), and chronic (CP) phases of disease who did not undergo transplant was 4-6 months, 1-1.5 years, and 3-8 years, respectively [1]. The only curative therapeutic option for CML was allogeneic hematopoietic stem cell transplantation (allo-HSCT), and all CML patients who had suitable human leukocyte antigen (HLA)-matched donors were considered candidates for allo-HSCT until 2002 [2].

It has been shown that imatinib treatment is superior to interferon alpha and low-dose cytarabine treatments in patients with CML [3], and later, TKI treatment was shown to result in long-term hematologic, cytogenetic, and molecular remission $[4,5,6]$. Therefore, the therapeutic landscape for CML has changed, and TKIs have become the first-line treatment for patients with CML. In 2002, TKIs became available for CML patients in Turkey $[7,8]$. Since 2002, allo-HSCT has remained the only proven curative option for $\mathrm{CML}$, but it is currently indicated only for patients who have failed to respond to TKIs, those who have mutations associated with TKI resistance (e.g., T315I), and those who are intolerant to TKIs $[8,9]$.

Although the discovery of TKIs has changed the indications for allo-HSCT in CML patients, allo-HSCT outcomes may have also been affected by the year of allo-HSCT due to the development of more successful transplantation techniques and supportive treatment options [10]. TKls may also be used after allo-HSCT to treat relapse after transplantation in CML patients. Therefore, in this retrospective study, we compared allo-HSCT outcomes as well as patient, disease, and transplantation characteristics in the pre- and post-TKI eras and pretransplant TKI usage, posttransplant therapeutic TKI usage, and rates of reaching hematologic complete remission (CR) at 3 months in patients with CML.

\section{Materials and Methods}

We conducted this study after it was approved by the institutional ethics committee. A total of $188 \mathrm{CML}$ patients underwent 193 allo-HSCTs (a second allo-HSCT was performed for five patients) at the Ankara University Department of Hematology and Bone Marrow Transplantation Unit between 1989 and 2012. CML clinical phases were defined according to the 2008 WHO criteria [11]. For this study, we defined the advanced phase as any phase other than $\mathrm{CP} 1$ (e.g., >chronic phase 1 (>CP1), AP, or BP). The majority of CML patients in the AP or BP of disease received acute myelogenous leukemia-type induction regimens before undergoing allo-HSCT.

We divided the patients into 2 groups: patients receiving alloHSCT before TKIs were available (the pre-TKI era group, before 2002, $n=128$ ) and patients receiving allo-HSCT after TKIs were available (the post-TKI era group, 2002 and after, $n=65$ ) (Supplement 1).

In the post-TKI era, 48 of 65 patients (73\%) received TKIs before allo-HSCT. We also evaluated these patients separately with regards to TKI effect on survival with two groups, a TKI-using group and a group not using TKIs, to differentiate the effect of pretransplant TKIs on allo-HSCT (Supplement 1).

Details about conditioning regimen, HLA matching status, graft-versus-host disease (GVHD) prophylaxis, definition and treatment of relapse, and supportive therapy are given in Supplement 1.

\section{Statistical Analysis}

Numeric variables are presented as medians. Categorical variables were compared by the chi-square test or Fisher exact test. The nonparametric Mann-Whitney $U$ test was used for noncategorical variables. GVHD was considered a categorical variable. Relapse and transplant-related mortality rates were calculated as time-dependent variables. Overall survival (OS) and disease-free survival (DFS) were calculated from the date of allo-HSCT. OS after relapse was calculated from the date of relapse. The distributions of OS and DFS durations in the two groups were estimated using the Kaplan-Meier method and compared using the log-rank test.

Recipient age, recipient sex, donor sex, stem cell source, conditioning regimen intensity, CML clinical phase, hematologic remission 3 months after allo-HSCT, and time from diagnosis to transplant were included in the multivariate analyses of survival. Logistical regression and a Cox model were used for risk factor analysis in DFS and OS. All reported p-values were two-sided, and $p<0.05$ was considered significant. Statistical analyses were performed using SPSS 16.0.

\section{Results}

Before 2002, allo-HSCT was performed in 321 patients, 128 of whom (40\%) had CML. Between 2002 and 2006, allo-HSCT was performed in 581 patients, 65 of whom (11\%) had CML $(p<0.001)$. After 2007, the frequency of CML patients among all patients receiving allo-HSCT further decreased to $5 \%$ $(n=18 / 360 ; p<0.001)$.

The time from diagnosis to transplantation was shorter in the pre-TKI era group than in the post-TKI era group (9.2 months versus 15.8 months, respectively; $p<0.001$, Table 1). The post- 


\begin{tabular}{|c|c|c|c|c|c|c|}
\hline & $\begin{array}{l}\text { Pre-TKI era } \\
(n=128)\end{array}$ & $\begin{array}{l}\text { Post-TKI era } \\
(n=65)\end{array}$ & p & $\begin{array}{l}\text { No TKIs used before } \\
\text { transplant }(n=145)\end{array}$ & $\begin{array}{l}\text { TKls used before } \\
\text { transplant }(n=48)\end{array}$ & p \\
\hline \multicolumn{7}{|c|}{ Time from diagnosis to transplantation } \\
\hline $\begin{array}{l}\text { Median } \\
\text { (range), months }\end{array}$ & $\begin{array}{l}9.2 \\
(1.6-129)\end{array}$ & $\begin{array}{l}15.8 \\
(3.3-266)\end{array}$ & $<0.001$ & $\begin{array}{l}9.0 \\
(1.6-129)\end{array}$ & $\begin{array}{l}19.0 \\
(4.1-266)\end{array}$ & $<0.001$ \\
\hline Median (range), years & $\begin{array}{l}34 \\
(14-48)\end{array}$ & $\begin{array}{l}34 \\
(18-58)\end{array}$ & 0.3 & $\begin{array}{l}33 \\
(14-48)\end{array}$ & $\begin{array}{l}38 \\
(18-58)\end{array}$ & 0.02 \\
\hline \multicolumn{7}{|l|}{ Recipient sex } \\
\hline $\begin{array}{l}\text { Male, n (\%) } \\
\text { Female, n (\%) }\end{array}$ & $\begin{array}{l}73(57) \\
55(43)\end{array}$ & $\begin{array}{l}39(60) \\
26(40)\end{array}$ & 0.7 & $\begin{array}{l}82(57) \\
63(43)\end{array}$ & $\begin{array}{l}30(63) \\
18(37)\end{array}$ & 0.4 \\
\hline \multicolumn{7}{|l|}{ Stem cell source } \\
\hline $\begin{array}{l}\text { BM, n (\%) } \\
\text { PB, n (\%) } \\
C B, n(\%)\end{array}$ & $\begin{array}{l}64(50) \\
64(50) \\
0(0)\end{array}$ & $\begin{array}{l}19(29) \\
44(68) \\
2(3)\end{array}$ & 0.009 & $\begin{array}{l}72(50) \\
73(50) \\
0(0)\end{array}$ & $\begin{array}{l}11(23) \\
35(73) \\
2(4)\end{array}$ & 0.002 \\
\hline \multicolumn{7}{|l|}{ CD34 count in product } \\
\hline Mean \pm SD, $106 / \mathrm{kg}$ & $4.8 \pm 3.5$ & $4.8 \pm 2.7$ & 0.5 & $4.8 \pm 3.4$ & $4.9 \pm 2.7$ & 0.4 \\
\hline \multicolumn{7}{|l|}{ GVHD prophylaxis } \\
\hline $\begin{array}{l}\text { CSA+Mtx, n (\%) } \\
\text { Others, n (\%) }\end{array}$ & $\begin{array}{l}120(94) \\
8(6)\end{array}$ & $\begin{array}{l}49(75) \\
16(25)\end{array}$ & $<0.001$ & $\begin{array}{l}131(90) \\
14(10)\end{array}$ & $\begin{array}{l}38(79) \\
10(21)\end{array}$ & 0.04 \\
\hline \multicolumn{7}{|c|}{ Disease status at transplantation } \\
\hline Median (range), years & $\begin{array}{l}32 \\
(9-56)\end{array}$ & $\begin{array}{l}32 \\
(0-65)\end{array}$ & 0.8 & $\begin{array}{l}31 \\
(9-56)\end{array}$ & $\begin{array}{l}36 \\
(0-65)\end{array}$ & 0.07 \\
\hline \multicolumn{7}{|l|}{ Donor sex } \\
\hline $\begin{array}{l}\text { Male, n (\%) } \\
\text { Female, n (\%) }\end{array}$ & $\begin{array}{l}72(56) \\
56(44)\end{array}$ & $\begin{array}{l}34(52) \\
31(48)\end{array}$ & 0.6 & $\begin{array}{l}64(44) \\
81(56)\end{array}$ & $\begin{array}{l}25(52) \\
23(48)\end{array}$ & 0.6 \\
\hline \multicolumn{7}{|l|}{ Donor type } \\
\hline $\begin{array}{l}\text { Related, n (\%) } \\
\text { Unrelated, n (\%) }\end{array}$ & $\begin{array}{l}128(100) \\
0(0)\end{array}$ & $\begin{array}{l}57(88) \\
8(12)\end{array}$ & $<0.001$ & $\begin{array}{l}145(100) \\
0(0)\end{array}$ & $\begin{array}{l}40(83) \\
8(17)\end{array}$ & $<0.001$ \\
\hline
\end{tabular}

TKI era group more frequently underwent unrelated donor transplantation and received more peripheral blood stem cells (PBSCs); they also more frequently underwent reducedintensity conditioning (RIC) and had more advanced disease (>CP1) (Table 1). Comparing patients for pretransplant TKI usage showed similar results. Patients using pretransplant TKIs had a longer time from diagnosis to transplantation, more unrelated donor transplantation, more received $\mathrm{PBSCs}$, more RIC regimen, and more advanced disease than the group not using TKIs before transplant. The group not using TKIs before transplant also included younger patients than did the group using pretransplant TKIs (Table 1). Rates of reaching hematologic CR at 3 months after allo-HSCT were similar between the pre- and post-TKI eras and between the groups using and not using TKIs before transplant (Table 1).

Engraftment, rate of hematologic remission at 3 months after allo-HSCT, rate of sinusoidal obstruction syndrome of the liver, 

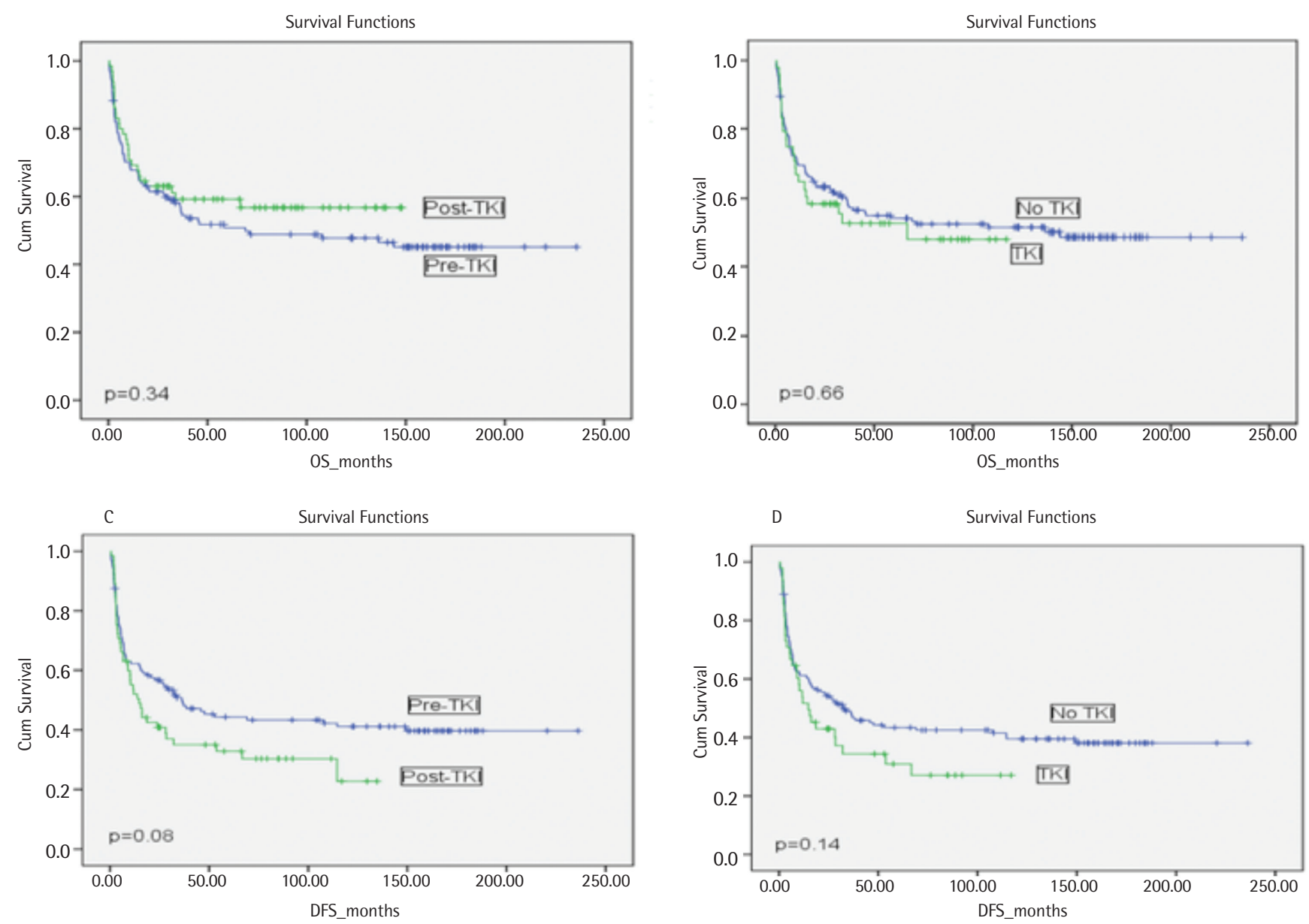

Figure 1. A. Overall survival in the tyrosine kinase inhibitor era. B. Overall survival in relation to tyrosine kinase inhibitor use. C. Diseasefree survival in the tyrosine kinase inhibitor era. D. Disease-free survival in relation to tyrosine kinase inhibitor use.

rate of acute and chronic GVHD, and rate of treatment-related mortality were similar in all groups. Hemorrhagic cystitis was more common in the pre-TKI era group (28.9\%) than in the post-TKI era group $(13.8 \%)(p=0.003)$ and more common in the group not using pretransplant TKIs $(27.6 \%)$ than in the group using pretransplant TKIs (12.5\%) $(p=0.01)$ (Table 2).

\section{Outcomes}

Relapsed/refractory disease after allo-HSCT was observed in 57 patients (relapse in 49 patients and refractory disease in 8 patients). Relapse was more common in the post-TKI era group (Table 2). DFS and OS were similar between the pre- and postTKI era groups and between the groups using and not using TKIs before transplant (Figure 1; Table 2). DFS and OS were also similar in CP1 and AP CML patients between the pre- and post-TKI era groups and between the groups using and not using TKIs before transplant (Table 2). However, pre-TKI patients with disease stage $>\mathrm{CP} 1$ had the worst OS rate, and this was significantly different from the OS rates of the other groups of patients (Figure 2).

OS after relapse in the post-TKI era group (mean: 94.2 months) was better than that in the pre-TKI era group (mean: 44.4 months). Patients received donor lymphocyte infusion (DLI) or TKIs, DLI plus TKI, or supportive therapy for the treatment of relapse. Most relapses (83\%) in the pre-TKI era patients occurred before 2002, during which time TKIs were unavailable. The mean survival rates of patients receiving therapeutic TKI after relapse with DLI (86.8 months) and without DLI (95.5 months) were longer than those for patients receiving DLI alone (58.3 months). Patients who only received supportive treatment had the worst survival (6.5 months) (Table 3 ).

The median OS survival at 5 years after relapse was higher in the post-TKI era patients than in the pre-TKI era patients (respectively $67 \%$ vs. $28 \%$ in all patients, $p=0.003 ; 83 \%$ vs. $32 \%$ in patients with CP1 CML, $p=0.006$; and $53 \%$ vs. $0 \%$ in patients with advanced disease, $p=0.04$ ) (data not shown).

Late relapses (9-12 years after allo-HSCT) occurred in 3 patients (one in the post-TKI era group and 2 in the pre-TKI era group). Two of these patients achieved CR with TKI treatment and survived. However, the third patient, who was diagnosed in the pre-TKI era, was resistant to TKI treatment and died.

In univariate analysis, recipient sex and phase of CML had a significant impact on DFS and OS (Table 4). Male recipients 


\begin{tabular}{|c|c|c|c|c|c|c|}
\hline & $\begin{array}{l}\text { Pre-TKI } \\
(n=128)\end{array}$ & $\begin{array}{l}\text { Post-TKI } \\
(n=65)\end{array}$ & $\mathbf{p}$ & $\begin{array}{l}\text { No TKIs used } \\
\text { before transplant } \\
(n=145)\end{array}$ & $\begin{array}{l}\text { TKIs used before } \\
\text { transplant }(n=48)\end{array}$ & p \\
\hline \multicolumn{7}{|l|}{ Engraftment } \\
\hline Engraftment, \% & 94.5 & 96.9 & 0.7 & 94.5 & 97.9 & 0.5 \\
\hline Neutrophil engraftment, mean $\pm S D$, days & $16 \pm 5$ & $17 \pm 6$ & 0.8 & $16 \pm 5$ & $17 \pm 7$ & 0.8 \\
\hline Platelet engraftment, mean $\pm S D$, days & $18 \pm 9$ & $18 \pm 12$ & 0.2 & $18 \pm 9$ & $18 \pm 13$ & 0.4 \\
\hline \multicolumn{7}{|l|}{ GVHD } \\
\hline Acute GVHD in 100 days, \% & 50.4 & 50.8 & 1.0 & 52.1 & 45.8 & 0.5 \\
\hline Grade $2-4$ acute GVHD in 100 days, \% & 33.1 & 27.7 & 0.5 & 34.0 & 22.9 & 0.2 \\
\hline Chronic GVHD in 2 years, \% & 66.1 & 72.2 & 0.4 & 68.0 & 68.4 & 1.0 \\
\hline \multicolumn{7}{|l|}{ Transplantation complications } \\
\hline Hemorrhagic cystitis, \% & 28.9 & 13.8 & 0.003 & 27.6 & 12.5 & 0.01 \\
\hline SOS, \% & 4.7 & 9.2 & 0.2 & 4.1 & 12.5 & 0.08 \\
\hline \multicolumn{7}{|l|}{ Hematologic CR after allo-HSCT } \\
\hline All patients, n (\%) & $108(84)$ & 57 (88) & 0.5 & $122(84)$ & 43 (90) & 0.4 \\
\hline CP1, n (\%) & $99(85)$ & $31(97)$ & 0.1 & $111(86)$ & $19(100)$ & 0.1 \\
\hline >CP1, n (\%) & $9(75)$ & $26(79)$ & 1.0 & $11(69)$ & 24 (83) & 0.5 \\
\hline \multicolumn{7}{|l|}{ Overall survival } \\
\hline \multicolumn{7}{|l|}{ All patients } \\
\hline $\begin{array}{l}\text { At } 1 \text { year, } \% \pm \mathrm{SE} \\
\text { At } 5 \text { years, } \% \pm \mathrm{SE} \\
\text { At } 10 \text { years, } \% \pm \mathrm{SE}\end{array}$ & $\begin{array}{l}67.8 \pm 4.1 \\
50.8 \pm 4.5 \\
47.8 \pm 4.6\end{array}$ & $\begin{array}{l}69.2 \pm 5.7 \\
59.5 \pm 6.2 \\
56.8 \pm 6.4\end{array}$ & 0.3 & $\begin{array}{l}69.5 \pm 3.8 \\
54.0 \pm 4.2 \\
51.3 \pm 4.3\end{array}$ & $\begin{array}{l}64.6 \pm 6.9 \\
52.5 \pm 7.5 \\
48.1 \pm 8.1\end{array}$ & 0.7 \\
\hline \multicolumn{7}{|l|}{ CP1 patients } \\
\hline $\begin{array}{l}\text { At } 1 \text { year, } \% \pm \mathrm{SE} \\
\text { At } 5 \text { years, } \% \pm \mathrm{SE} \\
\text { At } 10 \text { years, } \% \pm \mathrm{SE}\end{array}$ & $\begin{array}{l}70.5 \pm 4.2 \\
54.5 \pm 4.8 \\
51.2 \pm 4.8\end{array}$ & $\begin{array}{l}81.2 \pm 6.9 \\
68.6 \pm 8.2 \\
64.3 \pm 8.8\end{array}$ & 0.2 & $\begin{array}{l}71.9 \pm 4.0 \\
56.9 \pm 4.5 \\
53.9 \pm 4.6\end{array}$ & $\begin{array}{l}78.9 \pm 9.4 \\
62.7 \pm 11.2 \\
N R\end{array}$ & 0.8 \\
\hline \multicolumn{7}{|l|}{ >CP1 patients } \\
\hline $\begin{array}{l}\text { At } 1 \text { year, } \% \pm \mathrm{SE} \\
\text { At } 5 \text { years, } \% \pm \mathrm{SE} \\
\text { At } 10 \text { years, } \% \pm \mathrm{SE}\end{array}$ & $\begin{array}{l}41.7 \pm 14.2 \\
16.7 \pm 10.8 \\
16.7 \pm 10.8\end{array}$ & $\begin{array}{l}57.6 \pm 8.6 \\
49.6 \pm 9.2 \\
49.6 \pm 9.2\end{array}$ & 0.07 & $\begin{array}{l}50.0 \pm 12.5 \\
31.2 \pm 11.6 \\
31.2 \pm 11.6\end{array}$ & $\begin{array}{l}55.2 \pm 9.2 \\
45.3 \pm 10.1 \\
N R\end{array}$ & 0.4 \\
\hline \multicolumn{7}{|l|}{ TRM } \\
\hline \multicolumn{7}{|l|}{ All patients } \\
\hline $\begin{array}{l}\text { At } 3 \text { months, } \% \pm \mathrm{SE} \\
\text { At } 1 \text { year, } \% \pm \mathrm{SE} \\
\text { At } 5 \text { years, } \% \pm \mathrm{SE}\end{array}$ & $\begin{array}{l}16.4 \pm 3.3 \\
27.3 \pm 4.0 \\
39.0 \pm 4.5\end{array}$ & $\begin{array}{l}13.8 \pm 4.3 \\
23.7 \pm 5.4 \\
32.7 \pm 6.1\end{array}$ & 0.5 & $\begin{array}{l}15.2 \pm 3.0 \\
25.9 \pm 3.7 \\
36.4 \pm 4.2\end{array}$ & $\begin{array}{l}16.7 \pm 5.4 \\
27.9 \pm 6.6 \\
38.1 \pm 7.4\end{array}$ & 0.7 \\
\hline \multicolumn{7}{|l|}{ CP1 patients } \\
\hline $\begin{array}{l}\text { At } 3 \text { months, } \% \pm \mathrm{SE} \\
\text { At } 1 \text { year, } \% \pm \mathrm{SE} \\
\text { At } 5 \text { years, } \% \pm \mathrm{SE}\end{array}$ & $\begin{array}{l}13.8 \pm 3.2 \\
25.4 \pm 4.1 \\
36.8 \pm 4.7 \\
\end{array}$ & $\begin{array}{l}6.2 \pm 4.3 \\
15.8 \pm 6.5 \\
28.9 \pm 8.2 \\
\end{array}$ & 0.5 & $\begin{array}{l}13.2 \pm 3.0 \\
23.6 \pm 3.8 \\
34.6 \pm 4.4 \\
\end{array}$ & $\begin{array}{l}10.5 \pm 7.0 \\
21.1 \pm 9.4 \\
37.3 \pm 11.2 \\
\end{array}$ & 0.6 \\
\hline \multicolumn{7}{|l|}{ >CP1 patients } \\
\hline $\begin{array}{l}\text { At } 3 \text { months, } \% \pm \mathrm{SE} \\
\text { At } 1 \text { year, } \% \pm \mathrm{SE} \\
\text { At } 5 \text { years, } \% \pm \mathrm{SE}\end{array}$ & $\begin{array}{l}33.3 \pm 13.6 \\
51.2 \pm 14.8 \\
63.5 \pm 15.3\end{array}$ & $\begin{array}{l}21.2 \pm 7.2 \\
31.4 \pm 8.3 \\
35.0 \pm 8.6\end{array}$ & 0.1 & $\begin{array}{l}31.2 \pm 11.6 \\
44.4 \pm 12.6 \\
53.4 \pm 13.1\end{array}$ & $\begin{array}{l}21.7 \pm 7.5 \\
32.5 \pm 9.0 \\
37.7 \pm 9.4\end{array}$ & 0.3 \\
\hline
\end{tabular}




\begin{tabular}{|c|c|c|c|c|c|c|}
\hline \multicolumn{7}{|l|}{ Relapse/progression } \\
\hline \multicolumn{7}{|l|}{ All patients } \\
\hline At 1 year, $\% \pm \mathrm{SE}$ & $17.3 \pm 3.7$ & $31.2 \pm 6.2$ & 0.01 & $19.9 \pm 3.7$ & $27.4 \pm 7.2$ & 0.3 \\
\hline At 5 years, $\% \pm \mathrm{SE}$ & $32.4 \pm 5.0$ & $48.6 \pm 7.6$ & & $35.7 \pm 4.7$ & $46.2 \pm 9.9$ & \\
\hline \multicolumn{7}{|l|}{ CP1 patients } \\
\hline At 1 year, $\% \pm \mathrm{SE}$ & $13.7 \pm 3.5$ & $23.9 \pm 7.9$ & 0.07 & $16.6 \pm 3.6$ & $12.6 \pm 8.4$ & 0.7 \\
\hline At 5 years, $\% \pm \mathrm{SE}$ & $29.0 \pm 5.1$ & $40.7 \pm 9.6$ & & $32.1 \pm 4.9$ & $28.5 \pm 12.3$ & \\
\hline \multicolumn{7}{|l|}{ >CP1 patients } \\
\hline At 1 year, $\% \pm \mathrm{SE}$ & $59.5 \pm 17.5$ & $37.1 \pm 9.5$ & 0.3 & $51.4 \pm 15.0$ & $38.0 \pm 14.3$ & 0.4 \\
\hline At 5 years, $\% \pm \mathrm{SE}$ & $73.0 \pm 16.0$ & $60.8 \pm 13.8$ & & $70.8 \pm 14.0$ & $63.3 \pm 16.8$ & \\
\hline \multicolumn{7}{|l|}{ Disease-free survival } \\
\hline \multicolumn{7}{|l|}{ All patients } \\
\hline At 1 year, $\% \pm \mathrm{SE}$ & $62.3 \pm 4.3$ & $52.0 \pm 6.2$ & 0.08 & $61.2 \pm 4.1$ & $51.7 \pm 7.3$ & 0.1 \\
\hline At 5 years, $\% \pm \mathrm{SE}$ & $44.3 \pm 4.5$ & $32.9 \pm 6.1$ & & $43.4 \pm 4.2$ & $30.9 \pm 7.3$ & \\
\hline At 10 years, $\% \pm \mathrm{SE}$ & $41.2 \pm 4.6$ & $22.7 \pm 8.0$ & & $39.5 \pm 4.3$ & $27.1 \pm 7.4$ & \\
\hline \multicolumn{7}{|l|}{ CP1 patients } \\
\hline At 1 year, $\% \pm \mathrm{SE}$ & $66.2 \pm 4.4$ & $62.5 \pm 8.6$ & 0.3 & $64.9 \pm 4.2$ & $68.4 \pm 10.7$ & 0.7 \\
\hline At 5 years, $\% \pm \mathrm{SE}$ & $47.2 \pm 4.8$ & $40.6 \pm 8.7$ & & $46.4 \pm 4.5$ & $42.1 \pm 11.3$ & \\
\hline At 10 years, $\% \pm \mathrm{SE}$ & $43.7 \pm 4.8$ & $27.4 \pm 10.3$ & & $42.1 \pm 4.6$ & NR & \\
\hline \multicolumn{7}{|l|}{ >CP1 patients } \\
\hline At 1 year, $\% \pm \mathrm{SE}$ & $25.0 \pm 12.5$ & $41.7 \pm 8.7$ & 0.2 & $31.2 \pm 11.6$ & $40.5 \pm 9.2$ & 0.4 \\
\hline At 5 years, $\% \pm \mathrm{SE}$ & $16.7 \pm 10.8$ & $23.8 \pm 9.3$ & & $18.8 \pm 9.8$ & $21.8 \pm 10.7$ & \\
\hline At 10 years, $\% \pm \mathrm{SE}$ & $16.7 \pm 10.8$ & NR & & $18.8 \pm 9.8$ & NR & \\
\hline
\end{tabular}

A

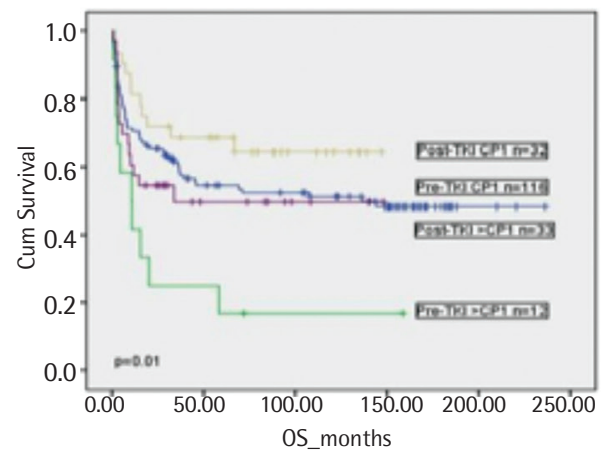

B

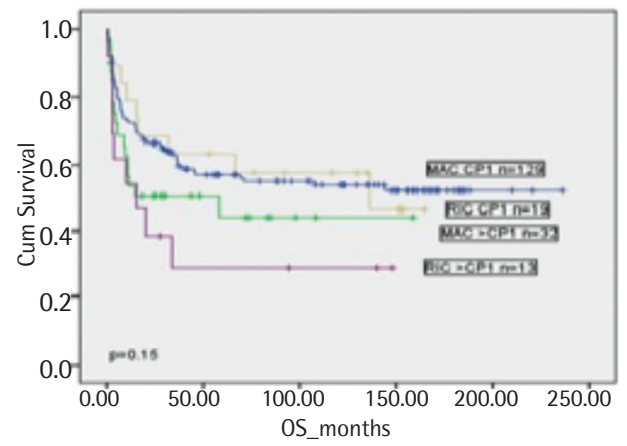

c

Survival Functions

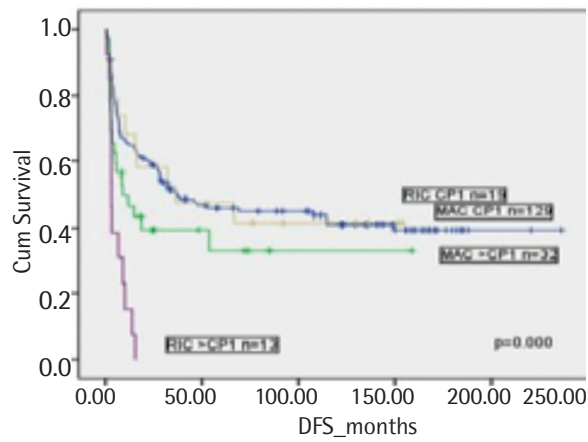

Figure 2. A) Overall survival by tyrosine kinase inhibitor era and phase of chronic myeloid leukemia. B) Overall survival by conditioning regimens and phase of chronic myeloid leukemia. C) Disease-free survival by conditioning regimens and phase of chronic myeloid leukemia.

receiving grafts from female donors had the worst DFS and OS rates (Table 4), most likely because of the higher incidence of chronic GVHD in those patients (61\% vs. 76\% for sex-matched and mismatched conditions, respectively, $p=0.03$ ). The receipt of $\mathrm{RIC}$ regimens did not significantly affect OS but was associated with lower DFS in patients with advanced CML (Figure 2; Table 4). Although allo-HSCT from an unrelated donor was performed only in post-TKI era patients, donor type did not affect DFS or OS (Table 4). Additionally, the univariate analysis showed that
TKI use and era of allo-HSCT did not affect OS or DFS (Tables 2 and 4; Figure 1). Hematologic CR at 3 months after allo-HSCT was also associated with better survival (Table 4).

In the multivariate analysis, male recipients (RR: 1.7, Cl 95\%: 1.2$2.5, p=0.007$ ) and patients with advanced disease (RR: 1.8, Cl 95\%: $1.2-2.8, p=0.005)$ were associated with worse DFS. Male recipients (RR: 1.7, Cl 95\%: 1.1-2.6, $p=0.02$ ) were also associated with worse OS. However, advanced disease phase was not associated with worse OS. DFS and OS rates were similar between the pre- and 


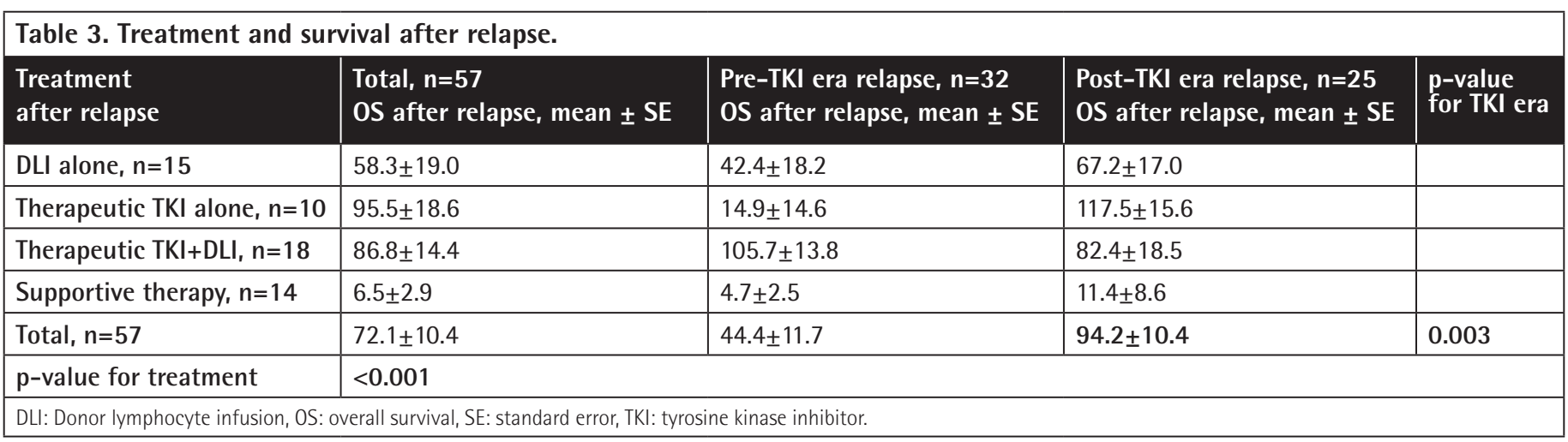

post-TKI groups. In addition, hematologic CR at 3 months after allo-HSCT was associated with better DFS (RR: 0.15, Cl 95\%: 0.090.24, $\mathrm{p}<0.001$ ) and OS (RR: 0.14, Cl 95\%: 0.09-0.23, p<0.001).

\section{Discussion}

In this study, we showed that the number of transplants for treatment of CML has significantly declined after TKIs became available (since 2002) and that allo-HSCT indications have changed. After TKIs, more CML patients receiving allo-HSCT had advanced disease. This might be important, especially for many developing countries that have limited beds and health care provider capacity to offer allo-HSCT. With this switch in allo-HSCT indication of CML, patients with more aggressive hematological malignancies can receive allo-HSCT in a more timely manner [16].

The clinical phase of CML is one of the most important factors affecting OS and DFS after allo-HSCT $[17,18]$. BP and AP patients had inferior outcomes to those of CP1 patients $[17,19]$. In a study performed during the TKI era, the outcomes of patients in CP1 were superior to the outcomes of patients in >CP1 [20]. Therefore, we defined patients with disease beyond CP1 as having advanced disease. However, we found that advanced disease only affects DFS, not OS. As expected, more patients with advanced disease (>CP1, AP, and BP) underwent allo-HSCT in the post-TKI era in our study. Despite the presence of more difficult cases in the post-TKI era, OS and DFS rates were similar in both eras. Due to the availability of first- and second-generation TKIs, allo-HSCT is performed late in most patients who require transplant; however, the difference between the groups for the time from diagnosis to HSCT was only approximately 6 months. This reasonably short delay may have contributed to the lack of inferior outcomes of patients in the post-TKI era.

Pretransplant TKI use did not affect OS or DFS in our study. A study by Khoury et al. [21] obtained similar findings, including no effect of pretransplant TKI use on OS. However, they did not provide the DFS rates of patients who received posttransplant TKIs. In our study, we showed that pretransplant TKI use did not affect DFS or OS in CML patients.
Jabbour et al. [22] showed that early complete response after TKI treatment in nontransplanted CML patients is the major determinant of patient outcome. Other studies reported that earlier and deep complete response after TKI treatment is correlated with better survival rates in CML patients $[23,24]$. However, to our knowledge, there is no study reporting the relationship between any response and overall survival in $\mathrm{CML}$ patients after allo-HSCT. Our study showed that early complete hematologic response after allo-HSCT is also one of the major determinants of CML patient survival.

The lower OS rates observed after relapse in pre-TKI era patients can easily be explained by the absence of TKIs. TKIs were available for posttransplant relapsed disease in the post-TKI era, and their use was associated with longer survival after CML relapse.

Savani et al. [25] reported that DLI with TKI treatment improved survival after allo-HSCT in 33 relapsing CML patients. They excluded BP CML patients within 30 days after DLI, but we included those patients in our study. Chalandon et al. [26] studied the occurrence of GVHD after DLI in CML patients and found that GVHD-related DLI was associated with mortality. Although we did not evaluate the occurrence of GVHD after DLI, we found that after allo-HSCT, TKI treatment (with or without DLI) for CML resulted in longer OS compared to the DLI-only approach. This finding explains the central role of TKIs in the treatment of relapse after allo-HSCT. Improvements in supportive measurements and other developments in the field most likely also contributed to the improved survival in the post-TKI era. Allo-HSCT outcomes of our CML patients may have also been affected by the year of allo-HSCT due to the development of more successful transplantation techniques and supportive treatment options [10].

OS was inferior in male recipients, in particular those who received grafts from female donors. Therefore, male recipients with female donors had the worst OS, most likely due to a higher incidence of chronic GVHD. When excluding male recipients receiving grafts from female donors, there were no significant differences between the OS or DFS rates among the other three groups. 


\begin{tabular}{|c|c|c|c|c|c|c|}
\hline & \multicolumn{3}{|l|}{ DFS } & \multicolumn{3}{|l|}{ OS } \\
\hline & $\begin{array}{l}\text { 5-year survival, } \\
\% \pm \text { SD, months }\end{array}$ & $\begin{array}{l}\text { 10-year survival, } \\
\% \pm \text { SD, months }\end{array}$ & $\mathbf{p}$ & $\begin{array}{l}\text { 5-year survival, } \\
\% \pm \text { SD, months }\end{array}$ & $\begin{array}{l}\text { 10-year survival, } \\
\% \pm \text { SD, months }\end{array}$ & $\mathbf{p}$ \\
\hline \multicolumn{7}{|l|}{ Clinical phase } \\
\hline $\begin{array}{l}\text { CP1 } \\
>\text { CP1 }\end{array}$ & $\begin{array}{l}45.9 \pm 4.2 \\
23.1 \pm 7.1\end{array}$ & $\begin{array}{l}41.0 \pm 4.3 \\
23.1 \pm 7.1\end{array}$ & $<0.001$ & $\begin{array}{l}57.5 \pm 4.1 \\
39.3 \pm 7.9\end{array}$ & $\begin{array}{l}54.0 \pm 4.3 \\
39.3 \pm 7.9\end{array}$ & 0.03 \\
\hline \multicolumn{7}{|c|}{ Hematologic CR at 3 months after allo-HSCT } \\
\hline $\begin{array}{l}\text { Reached } \\
\text { Not reached }\end{array}$ & $\begin{array}{l}46.2 \pm 4.0 \\
0.0 \pm 0.0 \\
\end{array}$ & $\begin{array}{l}41.5 \pm 4.1 \\
0.0 \pm 0.0\end{array}$ & $<0.001$ & $\begin{array}{l}60.2 \pm 3.9 \\
4.3 \pm 4.3\end{array}$ & $\begin{array}{l}56.8 \pm 4.0 \\
4.3 \pm 4.3\end{array}$ & $<0.001$ \\
\hline \multicolumn{7}{|c|}{ Stem cell source } \\
\hline $\begin{array}{l}\mathrm{PB} \\
\mathrm{BM}\end{array}$ & $\begin{array}{l}42.1 \pm 5.0 \\
40.0 \pm 5.5\end{array}$ & $\begin{array}{l}35.5 \pm 5.2 \\
38.3 \pm 5.5\end{array}$ & 0.9 & $\begin{array}{l}49.7 \pm 5.0 \\
59.5 \pm 5.5\end{array}$ & $\begin{array}{l}45.3 \pm 5.2 \\
57.9 \pm 5.5\end{array}$ & 0.1 \\
\hline \multicolumn{7}{|l|}{ TKI era } \\
\hline $\begin{array}{l}\text { Pre-TKI } \\
\text { Post-TKI }\end{array}$ & $\begin{array}{l}44.3 \pm 4.5 \\
32.9 \pm 6.1\end{array}$ & $\begin{array}{l}41.2 \pm 4.6 \\
22.7 \pm 8.0\end{array}$ & 0.08 & $\begin{array}{l}50.8 \pm 4.5 \\
59.5 \pm 6.2\end{array}$ & $\begin{array}{l}47.8 \pm 4.6 \\
56.8 \pm 6.4\end{array}$ & 0.3 \\
\hline \multicolumn{7}{|c|}{ Pretransplant TKI usage } \\
\hline $\begin{array}{l}\text { No } \\
\text { Yes }\end{array}$ & $\begin{array}{l}43.4 \pm 4.2 \\
30.9 \pm 7.3\end{array}$ & $\begin{array}{l}39.5 \pm 4.3 \\
27.1 \pm 7.4\end{array}$ & 0.1 & $\begin{array}{l}54.0 \pm 4.2 \\
52.5 \pm 7.5\end{array}$ & $\begin{array}{l}51.3 \pm 4.3 \\
48.1 \pm 8.1\end{array}$ & 0.7 \\
\hline \multicolumn{7}{|l|}{ Recipient sex } \\
\hline $\begin{array}{l}\text { Male } \\
\text { Female }\end{array}$ & $\begin{array}{l}34.2 \pm 4.7 \\
49.3 \pm 5.7\end{array}$ & $\begin{array}{l}30.1 \pm 4.7 \\
44.9 \pm 6.0\end{array}$ & 0.01 & $\begin{array}{l}45.9 \pm 4.9 \\
65.0 \pm 5.3\end{array}$ & $\begin{array}{l}40.6 \pm 5.0 \\
63.0 \pm 5.6\end{array}$ & 0.008 \\
\hline \multicolumn{7}{|l|}{ Recipient age } \\
\hline $\begin{array}{l}<35 \text { years } \\
35 \text { and above }\end{array}$ & $\begin{array}{l}39.1 \pm 4.9 \\
42.6 \pm 5.4 \\
\end{array}$ & $\begin{array}{l}33.5 \pm 5.0 \\
40.0 \pm 5.5 \\
\end{array}$ & 0.8 & $\begin{array}{l}54.0 \pm 5.0 \\
52.8 \pm 5.5 \\
\end{array}$ & $\begin{array}{l}51.2 \pm 5.1 \\
46.6 \pm 6.0\end{array}$ & 0.7 \\
\hline \multicolumn{7}{|c|}{ Time from diagnosis to allo-HSCT } \\
\hline $\begin{array}{l}1 \text { year or less } \\
>1 \text { year }\end{array}$ & \begin{tabular}{|l|}
$44.8 \pm 4.9$ \\
$35.2 \pm 5.4$ \\
\end{tabular} & \begin{tabular}{|l|}
$40.4 \pm 5.1$ \\
$31.8 \pm 5.4$ \\
\end{tabular} & 0.3 & \begin{tabular}{|l|}
$56.6 \pm 4.9$ \\
$45.8 \pm 5.7$ \\
\end{tabular} & $\begin{array}{l}53.9 \pm 5.0 \\
45.6 \pm 5.9 \\
\end{array}$ & 0.3 \\
\hline \multicolumn{7}{|c|}{ Conditioning regimen } \\
\hline $\begin{array}{l}\text { Ablative } \\
\text { RIC }\end{array}$ & \begin{tabular}{|l|}
$43.1 \pm 4.1$ \\
$28.1 \pm 7.9$ \\
\end{tabular} & \begin{tabular}{|l|}
$38.9 \pm 4.2$ \\
$24.6 \pm 7.7$ \\
\end{tabular} & 0.048 & $\begin{array}{l}55.1 \pm 4.0 \\
49.6 \pm 8.9 \\
\end{array}$ & $\begin{array}{l}51.3 \pm 4.2 \\
46.1 \pm 8.9 \\
\end{array}$ & 0.5 \\
\hline \multicolumn{7}{|l|}{ Donor type } \\
\hline $\begin{array}{l}\text { Related } \\
\text { Unrelated }\end{array}$ & $\begin{array}{l}41.1 \pm 3.7 \\
N R\end{array}$ & \begin{tabular}{|l|}
$36.9 \pm 3.8$ \\
$N R$
\end{tabular} & 0.3 & $\begin{array}{l}53.4 \pm 3.8 \\
N R \\
\end{array}$ & $\begin{array}{l}50.4 \pm 3.8 \\
N R\end{array}$ & 1.0 \\
\hline \multicolumn{7}{|l|}{ Donor sex } \\
\hline $\begin{array}{l}\text { Male } \\
\text { Female }\end{array}$ & $\begin{array}{l}43.1 \pm 4.9 \\
37.5 \pm 5.4 \\
\end{array}$ & $\begin{array}{l}40.1 \pm 5.0 \\
32.4 \pm 5.5 \\
\end{array}$ & 0.4 & $\begin{array}{l}58.3 \pm 4.9 \\
47.7 \pm 5.5 \\
\end{array}$ & $\begin{array}{l}54.1 \pm 5.1 \\
46.0 \pm 5.6 \\
\end{array}$ & 0.1 \\
\hline \multicolumn{7}{|c|}{ Acute GVHD in 100 days, presence } \\
\hline $\begin{array}{l}\text { No } \\
\text { Yes }\end{array}$ & $\begin{array}{l}47.3 \pm 5.3 \\
34.9 \pm 4.9 \\
\end{array}$ & $\begin{array}{l}43.7 \pm 5.5 \\
30.5 \pm 4.9 \\
\end{array}$ & 0.09 & $\begin{array}{l}64.3 \pm 5.2 \\
43.6 \pm 5.1 \\
\end{array}$ & $\begin{array}{l}61.2 \pm 5.4 \\
40.8 \pm 5.1 \\
\end{array}$ & 0.004 \\
\hline \multicolumn{7}{|c|}{ Grade 2-4 acute GVHD in 100 days, presence } \\
\hline $\begin{array}{l}\text { No } \\
\text { Yes }\end{array}$ & $\begin{array}{l}43.8 \pm 4.5 \\
34.3 \pm 6.2\end{array}$ & $\begin{array}{l}41.4 \pm 4.6 \\
27.0 \pm 6.2 \\
\end{array}$ & 0.055 & $\begin{array}{l}60.3 \pm 4.4 \\
39.5 \pm 6.4 \\
\end{array}$ & $\begin{array}{l}58.2 \pm 4.5 \\
34.9 \pm 6.4\end{array}$ & 0.001 \\
\hline \multicolumn{7}{|c|}{ Chronic GVHD in 2 years, presence } \\
\hline $\begin{array}{l}\text { No } \\
\text { Yes }\end{array}$ & \begin{tabular}{|l|}
$29.1 \pm 6.9$ \\
$55.1 \pm 4.8$ \\
\end{tabular} & \begin{tabular}{|l|}
$24.3 \pm 7.3$ \\
$50.1 \pm 5.0$ \\
\end{tabular} & $<0.001$ & \begin{tabular}{|l|}
$48.8 \pm 7.5$ \\
$68.0 \pm 4.5$ \\
\end{tabular} & $\begin{array}{l}45.3 \pm 7.7 \\
64.5 \pm 4.7 \\
\end{array}$ & 0.01 \\
\hline \multicolumn{7}{|c|}{ Donor/recipient sex match } \\
\hline $\begin{array}{l}\text { F-M } \\
F-F \\
M-M \\
M-F\end{array}$ & $\begin{array}{l}28.2 \pm 6.9 \\
48.7 \pm 8.3 \\
38.6 \pm 6.3 \\
50.2 \pm 7.7\end{array}$ & $\begin{array}{l}22.2 \pm 6.6 \\
44.6 \pm 8.6 \\
36.2 \pm 6.3 \\
45.7 \pm 8.3\end{array}$ & 0.04 & $\begin{array}{l}41.9 \pm 7.5 \\
54.7 \pm 8.2 \\
47.0 \pm 6.6 \\
74.1 \pm 6.7\end{array}$ & $\begin{array}{l}38.6 \pm 7.6 \\
54.7 \pm 8.2 \\
42.4 \pm 6.7 \\
70.2 \pm 7.4\end{array}$ & 0.03 \\
\hline
\end{tabular}


The complications of allo-HSCT were similar in the pre-TKI and post-TKI era groups, except in regards to hemorrhagic cystitis. Hemorrhagic cystitis occurred more frequently in the pre-TKI era, possibly due to the greater frequency of myeloablative conditioning regimen use during that period [27].

We found that pretransplant administration of TKIs has no negative impact on engraftment. Furthermore, we considered the fact that most of the patients in the post-TKI era group were challenged with an important drug, a TKI. This may have created clinically or biologically difficult cases, as observed in lymphoma patients with disease relapse shortly after being treated with chemotherapy regimens containing rituximab [28].

\section{Conclusion}

In conclusion, as expected, the frequency of allo-HSCT for CML patients sharply decreased after the introduction of TKIs. In recent years, this rate slightly increased, most likely due to TKI failure. Although CML patients who underwent allo-HSCT in the post-TKI era had more advanced disease, early and late outcomes were comparable between the pre- and post-TKI eras, mostly due to the high efficiency of TKIs for the treatment of relapses after allo-HSCT and advancements in the stem cell transplantation field. In addition, CR after allo-HSCT has improved survival rates and is the most prominent factor affecting OS and DFS.

\section{Ethics}

Ethics Committee Approval: It was approved by the institutional ethics committee; Informed Consent: Restrospective study.

\section{Authorship Contributions}

Concept: Muhit Özcan; Design: Mehmet Özen, Celalettin Üstün, Bengi Öztürk, Muhit Özcan; Data Collection or Processing: Mehmet Özen, Celalettin Üstün, Bengi Öztürk, Pervin Topçuoğlu, Mutlu Arat, Mehmet Gündüz, Erden Atilla, Gülşen Bolat, Önder Arslan, Taner Demirer, Hamdi Akan, Osman İlhan, Meral Beksaç, Günhan Gürman, Muhit Özcan; Analysis or Interpretation: Mehmet Özen, Celalettin Üstün, Bengi Öztürk Pervin Topçuoğlu; Literature Search: Mehmet Özen, Celalettin Üstün, Muhit Özcan; Writing: Mehmet Özen, Celalettin Üstün, Muhit Özcan.

Conflict of Interest: The authors of this paper have no conflicts of interest, including specific financial interests, relationships, and/or affiliations relevant to the subject matter or materials included.

\section{Supplement 1. TKI treatment before allogeneic hematopoietic stem cell transplantation.}

From 2002 to 2006, although TKIs were available for clinical use, their long-term effects were unknown; therefore, allo-HSCT was performed for all CML patients during that time period. After 2006, allo-HSCT was mainly considered for TKI-resistant/intolerant CML patients or CML patients in advanced phases of the disease. In the post-TKI era, allo-HSCT was performed in 65 CML patients: 6 patients in BP, 5 patients in AP, 22 patients in the second chronic phase (CP2), and 32 patients in the first chronic phase (CP1) (7 patients were resistant/intolerant to TKIs, 12 patients were sensitive to TKIs, and 13 patients did not receive TKIs based on the physician's or patient's preference due to the lack of knowledge regarding their long-term effects).

Most patients using TKIs before allo-HSCT were treated with imatinib alone $(n=41), 4$ patients received both imatinib and dasatinib, and 3 patients were treated with imatinib, dasatinib, and nilotinib before transplantation. Mutational analysis was performed for 9 patients, and only one patient was positive for the T315I mutation.

\section{Conditioning Regimen}

The most frequently used myeloablative conditioning (MAC) regimen contained combined cyclophosphamide (CY) (120 mg/kg i.v.) and busulfan (3.2 mg/kg i.v. or $4 \mathrm{mg} / \mathrm{kg}$ p.o., 4 days) treatment with or without antithymocyte globulin (ATG) (10 mg/kg/day, 4 days) and combined CY (120 $\mathrm{mg} / \mathrm{kg}$ ) and fractionated total-body irradiation (12 Gy) treatment with or without ATG (10 mg/kg/day, 4 days).

Fludarabine-based regimens have been used as RIC regimens: combined fludarabine ( $30 \mathrm{mg} / \mathrm{m}^{2}$ i.v., 6 days) and busulfan ( $3.2 \mathrm{mg} / \mathrm{kg}$ i.v. or $4 \mathrm{mg} /$ $\mathrm{kg}$ p.o., 2 days) treatment with or without ATG (10 mg/kg/day, 4 days) or combined fludarabine $\left(30 \mathrm{mg} / \mathrm{m}^{2}, 6\right.$ days $)$ and cytarabine $\left(3 \mathrm{~g} / \mathrm{m}^{2}\right.$ b.i.d., 4 days) treatment with or without ATG (10 mg/kg/day, 4 days). We did not perform in vitro T-cell depletion; however, in vivo T-cell depletion was accomplished by ATG administration in cases of a mismatched and/or unrelated donor (URD) after both MAC and RIC conditioning regimens.

\section{HLA Matching Status}

HLA matching status was defined as follows: well matched if recipient/donor pairs had either no identified HLA mismatches and informative data for at least 6 loci or matching alleles at HLA-A, -B, and -DRB1; partially matched if recipient/donor pairs had a defined, single-locus mismatch and/or missing HLA data; and mismatched if recipient/donor pairs had $\geq 2$ allele or antigen mismatches [12,13]. URD was started at our institution after 2002 for patients who had no HLA-matched donor or related donor with 1 allele mismatched and HLA match statuses were studied for URD transplants with at least 10 loci or alleles including HLA-A, $-B_{1}-C_{1}-D Q$, and -DRB1. After 1998, RIC regimens were administered to 21 patients due to either advanced age ( $\geq 50$ years) or comorbidity. Eleven patients received RIC transplant in a clinical trial comparing the intensity of conditioning regimens in CP CML patients. 


\section{GVHD Prophylaxis}

GVHD prophylaxis consisted of methotrexate (Mtx) at $15 \mathrm{mg} / \mathrm{m}^{2}$ on day +1 and $10 \mathrm{mg} / \mathrm{m}^{2}$ on days +3 and +6 (and additionally on day +11 for unrelated donor allo-HSCT) and daily cyclosporine (CSA) from day -1 (or -3 for unrelated donor allo-HSCT) to day +180 .

\section{Defining and Treating Relapse}

Relapse after allo-HSCT was defined by molecular, cytogenetic, or hematologic findings. Between 1989 and 1999, patients were followed cytogenetically, and molecular evaluation was not the main technique for remission assessment of CML patients. By 1999, molecular techniques were primarily used in place of cytogenetic techniques. Both molecular and cytogenetic data after allo-HSCT were only available after 1999; thus, these data were not included in the study. After 1999, patients were followed molecularly by testing BCR-ABL transcripts in RNA samples of peripheral blood or bone marrow starting at the time of allo-HSCT using a RO-PCR method (T922, LightCycler Quantification, Roche Diagnostics, Munich, Germany). The molecular methods for BCR-ABL1 and chimerism studies were performed every 3 months until 1 year, every 6 months until 5 years, and every 1 year until 10 years after allo-HSCT. Logarithmically increasing levels of $B C R-A B L$ transcript levels in at least 2 consecutive tests were defined as molecular relapse. Hematologic complete remission was defined as the detection of leukocytes at $<10,000 / \mu \mathrm{L}$, platelets at $<450,000 / \mu \mathrm{L}$, and basophils at $<5 \%$; the absence of myeloblasts, myelocytes, and promyelocytes in peripheral blood; myeloblasts at $<5 \%$ in bone marrow; and the absence of a palpable spleen on physical examination.

Chimerism was analyzed by PCR-based amplification of short tandem repeats (3130 Genetic Analyzer, Applied Biosystems, Foster City, CA, USA). An increase in recipient signals of more than $5 \%$ in sequential estimations of molecular chimerism compared to the prior level was considered as graft failure. In patients with graft failure or molecular/hematologic relapse, escalated doses of donor lymphocyte infusions (CD3+ cells in $1 \times 10^{7}, 5 \times 10^{7}$, and $1 \times 10^{8}$ doses) were administered sequentially each month (if no response had been observed and no GVHD had developed since the previous infusion) and/or TKIs as a therapeutic option were administered.

\section{Supportive Therapy}

Prophylactic platelet transfusion was given if the platelet count was $<20 \times 10^{9} / \mathrm{L}$. Red blood cell transfusion was given if hemoglobin was $<7 \mathrm{~g} /$ $\mathrm{dL}$ or $<10 \mathrm{~g} / \mathrm{dL}$ depending on the patient's history of cardiovascular events. All blood products were irradiated and filtered. Infection prophylaxis has not changed since 1988 and includes acyclovir, fluconazole, and trimethoprim/sulfamethoxazole for all patients. Ciprofloxacin was added to these antimicrobials for patients receiving MAC. All patients were treated following the guidelines reported by the Infectious Diseases Society of America [14] and the Turkish National Febrile Neutropenia Study Group [15].

\section{References}

1. Lee SJ. Chronic myelogenous leukaemia. Br J Haematol 2000;111:993-1009.

2. Champlin RE, Golde DW. Chronic myelogenous leukemia: recent advances. Blood 1985;65:1039-1047.

3. O'Brien SG, Guilhot F, Larson RA, Gathmann I, Baccarani M, Cervantes F, Cornelissen JJ, Fischer T, Hochhaus A, Hughes T, Lechner K, Nielsen JL, Rousselot P, Reiffers J, Saglio G, Shepherd J, Simonsson B, Gratwohl A, Goldman JM, Kantarjian H, Taylor K, Verhoef G, Bolton AE, Capdeville R, Druker BJ; IRIS Investigators. Imatinib compared with interferon and low-dose cytarabine for newly diagnosed chronic-phase chronic myeloid leukemia. N Engl J Med 2003;348:994-1004.

4. Grigg A, Hughes T. Role of allogeneic stem cell transplantation for adult chronic myeloid leukemia in the imatinib era. Biol Blood Marrow Transplant 2006;12:795-807.

5. Saussele $S$, Lauseker $M$, Gratwohl $A$, Beelen DW, Bunjes D, Schwerdtfeger $R$, Kolb HJ, Ho AD, Falge $C$, Holler E, Schlimok G, Zander AR, Arnold R, Kanz $L$, Dengler $R$, Haferlach $C$, Schlegelberger $B$, Pfirrmann $M$, Müller MC, Schnittger S, Leitner A, Pletsch N, Hochhaus A, Hasford J, Hehlmann

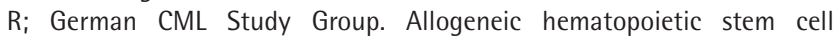
transplantation (allo SCT) for chronic myeloid leukemia in the imatinib era: evaluation of its impact within a subgroup of the randomized German CML Study IV. Blood 2010;115:1880-1885.

6. Simon W, Segel GB, Lichtman MA. Early allogeneic stem cell transplantation for chronic myelogenous leukemia in the imatinib era: a preliminary assessment. Blood Cells Mol Dis 2006;37:116-124.

7. Lindoerfer D, Hoffmann VS, Rosti G, Castagnetti F, Saussele S, Guilhot J, Simonsson B, Steegmann JL, Mayer J, Indrak K, Turkina AG, Zaritskey A, Labar B, Zupan IP, Thielen N, Clark RE, Thaler J, Melanthiou F, Everaus H, Porkka $K$, Bogdanovic AD, Schubert-Fritschle G, Panagiotidis $P$, Masszi T, Lejniece $S$, Griskevicius L, Hellmann A, Prejzner W, Sacha T, Almeida A, Dyagil I, Colita A, Mihaylov G, HehImann R, Hasford J, Baccarani M. The EUTOS Population-
Based Registry: Evaluation of baseline characteristics and first treatment choices of 2983 newly diagnosed chronic myeloid leukemia (CML) patients from 20 European countries. In: 19th Congress of the European Hematology Association; Milan, Italy; 12-15 June 2014.

8. Baccarani M, Cortes J, Pane F, Niederwieser D, Saglio G, Apperley J, Cervantes F, Deininger M, Gratwohl A, Guilhot F, Hochhaus A, Horowitz M, Hughes T, Kantarjian H, Larson R, Radich J, Simonsson B, Silver RT, Goldman J, Hehlmann R; European LeukemiaNet. Chronic myeloid leukemia: an update of concepts and management recommendations of European LeukemiaNet. J Clin Oncol 2009;27:6041-6051.

9. Jabbour $E_{1}$ Kantarjian $H$. Chronic myeloid leukemia: 2012 update on diagnosis, monitoring, and management. Am J Hematol 2012;87:1037-1045.

10. O'Meara A, Holbro A, Meyer S, Martinez M, Medinger M, Buser A, Halter J, Heim D, Gerull S, Bucher C, Rovo A, Kühne T, Tichelli A, Gratwohl A, Stern $M$, Passweg JR. Forty years of haematopoietic stem cell transplantation: a review of the Basel experience. Swiss Med Wkly 2014;144:w13928.

11. National Cancer Institute. Chronic Myelogenous Leukemia Treatment (PDQ) - Stages of Chronic Myelogenous Leukemia. Rockville, MD, USA, NCl, 2015. Available online at http://www.cancer.gov/cancertopics/pdq/treatment/ $\mathrm{CML} /$ Patient/page2.

12. Morishima $Y$, Sasazuki T, Inoko $H$, Juji $T$, Akaza $T$, Yamamoto $K$, Ishikawa $Y$, Kato S, Sao H, Sakamaki H, Kawa K, Hamajima N, Asano S, Kodera Y. The clinical significance of human leukocyte antigen (HLA) allele compatibility in patients receiving a marrow transplant from serologically HLA-A, HLA-B, and HLA-DR matched unrelated donors. Blood 2002;99:4200-4206.

13. Petersdorf EW, Kollman C, Hurley CK, Dupont B, Nademanee A, Begovich $A B$, Weisdorf $D$, McGlave P. Effect of HLA class II gene disparity on clinical outcome in unrelated donor hematopoietic cell transplantation for chronic myeloid leukemia: the US National Marrow Donor Program Experience. Blood 2001;98:2922-2929. 
14. Hughes WT, Armstrong D, Bodey GP, Brown AE, Edwards JE, Feld R, Pizzo P, Rolston KV, Shenep JL, Young LS. 1997 guidelines for the use of antimicrobial agents in neutropenic patients with unexplained fever. Infectious Diseases Society of America. Clin Infect Dis 1997;25:551-573.

15. Febril Nötropeni Çalışma Grubu. Febril nötropenik hastalarda tanı ve tedavi kılavuzu. Flora 2004;9:5-28 (in Turkish)

16. Gratwohl A, Baldomero $H$, Aljurf $M$, Pasquini MC, Bouzas LF, Yoshimi $A$, Szer J, Lipton J, Schwendener A, Gratwohl M, Frauendorfer K, Niederwieser $D$, Horowitz M, Kodera $Y_{;}$Worldwide Network of Blood and Marrow Transplantation. Hematopoietic stem cell transplantation: a global perspective. JAMA 2010;303:1617-1624.

17. Lee SJ, Kukreja M, Wang T, Giralt SA, Szer J, Arora M, Woolfrey AE, Cervantes F, Champlin RE, Gale RP, Halter J, Keating A, Marks DI, McCarthy PL, Olavarria E, Stadtmauer EA, Abecasis M, Gupta V, Khoury HJ, George B, Hale GA, Liesveld JL, Rizzieri DA, Antin JH, Bolwell BJ, Carabasi MH, Copelan E, Ilhan O, Litzow MR, Schouten HC, Zander AR, Horowitz MM, Maziarz RT. Impact of prior imatinib mesylate on the outcome of hematopoietic cell transplantation for chronic myeloid leukemia. Blood 2008;112:3500-3507.

18. Pavlu J, Szydlo RM, Goldman JM, Apperley JF. Three decades of transplantation for chronic myeloid leukemia: what have we learned? Blood 2011;117:755-763.

19. Speck B, Bortin MM, Champlin R, Goldman JM, Herzig RH, McGlave PB, Messner HA, Weiner RS, Rimm AA. Allogeneic bone-marrow transplantation for chronic myelogenous leukaemia. Lancet 1984;1:665-668.

20. Oyekunle A, Zander AR, Binder M, Ayuk F, Zabelina T, Christopeit M, Stübig T, Alchalby H, Schafhausen P, Lellek H, Wolschke C, Müller I, Bacher U, Kröger $\mathrm{N}$. Outcome of allogeneic SCT in patients with chronic myeloid leukemia in the era of tyrosine kinase inhibitor therapy. Ann Hematol 2013;92:487-496.

21. Khoury HJ, Kukreja M, Goldman JM, Wang T, Halter J, Arora M, Gupta V, Rizzieri DA, George B, Keating A, Gale RP, Marks DI, McCarthy PL, Woolfrey A, Szer J, Giralt SA, Maziarz RT, Cortes J, Horowitz MM, Lee SJ. Prognostic factors for outcomes in allogeneic transplantation for $\mathrm{CML}$ in the imatinib era: a CIBMTR analysis. Bone Marrow Transplant 2012;47:810-816.

22. Jabbour E, Kantarjian H, O'Brien S, Shan J, Quintas-Cardama A, Faderl S, Garcia-Manero G, Ravandi F, Rios MB, Cortes J. The achievement of an early complete cytogenetic response is a major determinant for outcome in patients with early chronic phase chronic myeloid leukemia treated with tyrosine kinase inhibitors. Blood 2011;118:4541-4546.

23. Branford $S$, Yeung DT, Parker WT, Roberts ND, Purins $L$, Braley JA, Altamura HK, Yeoman AL, Georgievski J, Jamison BA, Phillis S, Donaldson Z, Leong M, Fletcher L, Seymour JF, Grigg AP, Ross DM, Hughes TP. Prognosis for patients with CML and $>10 \%$ BCR-ABL1 after 3 months of imatinib depends on the rate of BCR-ABL1 decline. Blood 2014;124:511-518.

24. Hehlmann $R$, Müller $M C$, Lauseker $M$, Hanfstein $B$, Fabarius $A$, Schreiber A, Proetel U, Pletsch N, Pfirrmann M, Haferlach C, Schnittger S, Einsele $H$, Dengler J, Falge C, Kanz L, Neubauer A, Kneba M, Stegelmann F, Pfreundschuh $\mathrm{M}$, Waller CF, Spiekermann K, Baerlocher GM, Ehninger G, Heim D, Heimpel H, Nerl C, Krause SW, Hossfeld DK, Kolb HJ, Hasford J, Saußele $\mathrm{S}$, Hochhaus A. Deep molecular response is reached by the majority of patients treated with imatinib, predicts survival, and is achieved more quickly by optimized high-dose imatinib: results from the randomized CMLstudy IV. J Clin Oncol 2014;32:415-423.

25. Savani BN, Montero A, Kurlander R, Childs R, Hensel N, Barrett AJ. Imatinib synergizes with donor lymphocyte infusions to achieve rapid molecular remission of CML relapsing after allogeneic stem cell transplantation. Bone Marrow Transplant 2005;36:1009-1015.

26. Chalandon $Y$, Passweg JR, Schmid $C$, Olavarria E, Dazzi $F$, Simula MP, Ljungman $P$, Schattenberg $A$, de Witte $T$, Lenhoff $S$, Jacobs $P$, Volin $L$, lacobelli S, Finke J, Niederwieser D, Guglielmi C; Chronic Leukemia Working Party of European Group for Blood and Marrow Transplantation. Outcome of patients developing GVHD after DLI given to treat CML relapse: a study by the Chronic Leukemia Working Party of the EBMT. Bone Marrow Transplant 2010;45:558-564.

27. Topcuoglu P, Arat M, Ozcan M, Arslan O, Ilhan O, Beksac M, Gurman G. Casematched comparison with standard versus reduced intensity conditioning regimen in chronic myeloid leukemia patients. Ann Hematol 2012;91:577586.

28. Gisselbrecht C, Glass B, Mounier N, Singh Gill D, Linch DC, Trneny M, Bosly A, Ketterer N, Shpilberg O, Hagberg H, Ma D, Brière J, Moskowitz CH, Schmitz $\mathrm{N}$. Salvage regimens with autologous transplantation for relapsed large B-cell lymphoma in the rituximab era. J Clin Oncol 2010;28:4184-4190. 